\title{
REVISTAMATĒRIA
}

ISSN 1517-7076 artículo e11788, 2017

\section{Mechanical and microstructural behavior evolution of non-ferrous metals by ECASD}

\author{
Cesar Augusto Isaza Merino ${ }^{1}$, Daniel Peláez ${ }^{2}$, Patricia Fernández-Morales ${ }^{2}$, \\ Emigdio Mendoza ${ }^{2}$, Juan Manuel Meza ${ }^{1}$
}

\author{
${ }^{1}$ Facultad de Minas, Universidad Nacional de Colombia, Colombia. \\ e-mail: caisaza@unal.edu.co,jmmezam@unal.edu.co. \\ ${ }^{2}$ Escuela de Ingenierías, Universidad Pontificia Bolivariana, Colombia. \\ e-mail: danielpelaez13@gmail.com,patricia.fernandez@upb.edu.co,emigdio.mendoza@upb.edu.co.
}

\section{RESUMEN}

En este estudio, se usó la técnica de extrusión de láminas de una aleación de aluminio AA-1100-O y una aleación de magnesio AZ31-O por medio de un dado de cizalladura con un ángulo de $135^{\circ}$ (ECASD, por sus siglas en inglés) para producir la deformación plástica en las aleaciones, que permita obtener microestructuras con tamaños de grano pequeños para aumentar su plasticidad en situaciones específicas de trabajo. En este estudio, se evaluó el cambio en las propiedades microestructurales y mecánicas por medio de microscopía óptica y ensayos mecánicos como microdureza y ensayos de tensión. La técnica de deformación plástica severa ECASD produce cambios en las propiedades mecánicas, sin cambios significativos en la masa de las muestras con pequeños cambios en las características micro-estructurales en el núcleo del material. Sin embargo, el proceso ECASD produce importantes cambios microestructurales cerca de la superficie de los materiales investigados, por tanto, la dureza está fuertemente modificada en esta región. Esto es debido a las altas tensiones de contacto y fricción desarrolladas con la matriz durante el proceso de ECASD.

Palabras clave: Aleación de aluminio, aleación de magnesio, deformación por cizalladura, deformación plástica severa.

\begin{abstract}
In this study, Equal-Channel Angular Sheet Drawing- ECASD with a die set at $135^{\circ}$ was used to produce plastic deformation onto an aluminum alloy AA-1100-O and a magnesium alloy AZ31-O samples, expecting a decreasing the grain size in order to increase the plasticity of these alloys under certain specific working conditions. In this study, the microstructural and mechanical properties changed due to this process were analyzed by optical microscopy and mechanical testing like micro-hardness and tension test. ECASD produces work hardening with no significant dimensional changes into the flat specimens with small changes in the microstructural characteristics. The ECASD process also produces important microstructural changes close to the surface of the investigated samples therefore its hardness is strongly modified in this region. This is due to the high contact stresses and friction developed with the die during the ECASD process.
\end{abstract}

Keywords: Aluminium alloy, magnesium alloy, shear strain, severe plastic deformation

\section{INTRODUCTION}

The plastic deformation behavior of magnesium alloys has been of recent interest due to increasing demand for the application of light materials in the transportation industry. Magnesium is the lightest structural metal with potential use in the industry. It has a hexagonal crystal structure that affects its mechanical properties, specially its plastic deformation at room temperature. However, many researchers are focusing their studies in magnesium alloys due to their potential applications in the aeronautical and automotive industry [1-4].

The poor ductility of magnesium alloys has been attributed to its high anisotropic dislocation slip behavior [5]. The basal slip system provides only two independent slip systems, however it is necessary to have five independent systems for homogeneous deformation [6], as it is the case of aluminum alloys. In order to provide a solution for plastic deformation of metallic materials with poor ductility, the severe plastic defor- 
mation (SPD) techniques were developed; these techniques allow to get ultrafine grained materials (UFG) with different mechanical behavior and, in some cases, better tensile strength.

Techniques like equal channel angular extrusion (ECAP) were studied by P. Bridgman and Segal $[7,8]$. Other deformation processes were developed using rolling facilities combined with the principles of ECAP, among these: the continuous confined strip shearing (C2S2), the dissimilar-channel angular pressing (DCAP) and equal-channel angular rolling (ECAR) [9]. Such techniques produce heterogeneous strain distribution in the sheets under process [10]. One of the most used magnesium alloy to obtain metallic sheets is the AZ31B, which have been investigated by means of SPD processes by Yamashita [11] and Utsunomiya [12]. They showed that decreasing the grain size increases more than $40 \%$ of elongation at room temperature. Other study showed that the equal-channel angular sheet extrusion (ECASE) for continuous processing of free interstice (IF) steels increase considerably both its yield strength and ultimate strength values [10]. One interesting deformation process is called equal channel angular sheet drawing (ECASD) [13]. It is based in previous works proposed by Suriadi and Thomson in 1997 [14], a billet is passed through intersecting channels, thus eliminating problems related to the compressive loads of ECAP. The aim of the present work is to evaluate the mechanical behavior and micro-structural evolution of magnesium alloy AZ31B and aluminum alloy AA1100 both through ECASD technique.

\section{MATERIALS AND METHODS}

A commercial flat plates (annealing) of aluminum alloy AA 1100-O and magnesium alloy AZ31-O with thicknesses of $3 \mathrm{~mm}$ and $4 \mathrm{~mm}$, respectively, were used in this study. The flat plates were cut into specimens with dimensions of $50 \mathrm{~mm} \times 200 \mathrm{~mm}$. These samples were processed by ECASD at room temperature through a die with an intersection angle of $135^{\circ}$ (see Figure 1). An INSTRON 5582 testing machine set to a pull velocity of $5 \mathrm{~mm} \cdot \mathrm{min}^{-1}$ was used. The specimens were subjected to three consecutive ECASD passes and were polished after each pass for eliminating the surface damage generated during ECASD process. They were kept in the same orientation respect to its longitudinal axis between each pass, which is referred in the literature as route $\mathrm{A}[15-17]$.
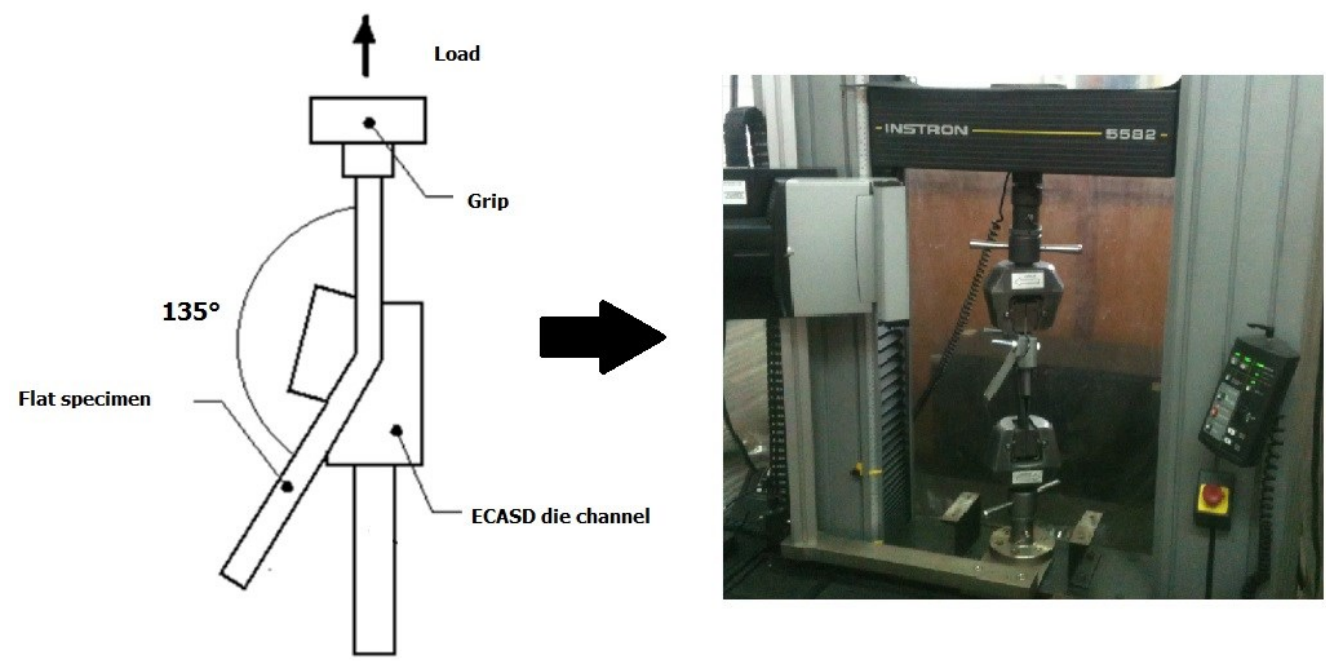

Figure 1: ECASD dispositive.

Samples for optical microscopy (OM) observation and mechanical testing were sliced parallel to the extrusion direction and then were polished using standard metallographic preparation and etching techniques. Aluminum alloy samples were etched with a solution of sodium hydroxide dissolved in distilled water $(2.0 \mathrm{~g}$ of $\mathrm{NaOH}$ in $100 \mathrm{ml}$ of water) while the magnesium alloy was etched with Nital at $8 \%$ in volume. The microstructure examination was carried out on LV100 series Nikon optical microscope coupled with a Nikon digital camera.

Tensile tests were conducted on an INSTRON 5582 testing machine at a constant strain rate of $0.5 \mathrm{~mm} / \mathrm{min}$. Tensile samples were of sub-size dimensions according to ASTM E-8 standard (gage length of $25 \mathrm{~mm}$ and width of $6 \mathrm{~mm}$ ). Micro-hardness test were conducted on a Zwick-Roell Vickers microindenter and the loads of $300 \mathrm{~g}$ and $100 \mathrm{~g}$ were used. 


\section{RESULTS AND DISCUSION}

\subsection{Microstructure analysis}

The typical OM micrographs obtained from the as-received and ECAP processed aluminum alloy samples are shown in Figure 2. Prior to deformation, the grains did not have a defined orientation induced by previous processes, indicating that the material was annealed (Figure 2(a)). Precipitates in the as-received sample (dark particles) show an almost continuous distribution along the grain boundaries and inside the grains. However, after three ECASD passes most of them are located along the grain boundaries as is shown in the Figure 2(b), where the grains are oriented in the pulling direction after three ECASD passes.
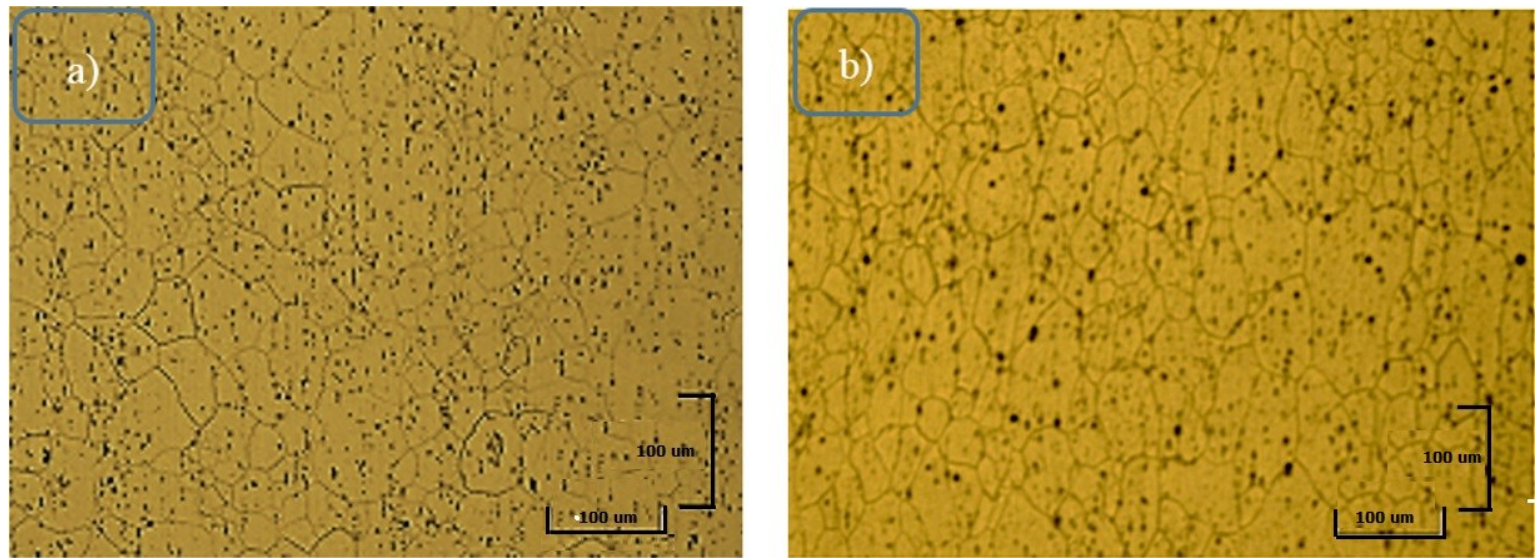

Figure 2: Aluminum alloy AA- 1100 microstructure (a) As-received, (b) three ECASD passes.

Figure 3 shows micrographs obtained from the as-received and ECASD processed magnesium alloy. The changes in the microstructure after ECASD process are not evident. However, it shows some microstructural transformation. In the as-received state (Figure 3(a)), the grains do not have a defined orientation induced by previous processes. Besides, there is a non-homogeneous microstructure, showing different morphologies such as small and equiaxed grains, larger and in some cases elongated grains, and some precipitates were found. This microstructure is typical of magnesium alloy plastically deformed with partial annealing heat treatment [18].

After three ECASD passes, the microstructure did not present obvious changes as shown in Figure 3 (b). However, the microstructure is twinned in some zones due to the deformation process. This shear bands are parallel to the ECASD direction which is consistent with the slip lines of the third pass through the die. After ECASD process, magnesium alloy sheet allows a very strong basal texture generated by the process, where the c-axis of HCP lattice is predominantly aligned parallel to the sheet normal, because the state of stress causes an extension in the sheet normal direction will activate twinning at low stress, while a state of stress that causes contraction normal to the sheet plane does not activate twinning [19].
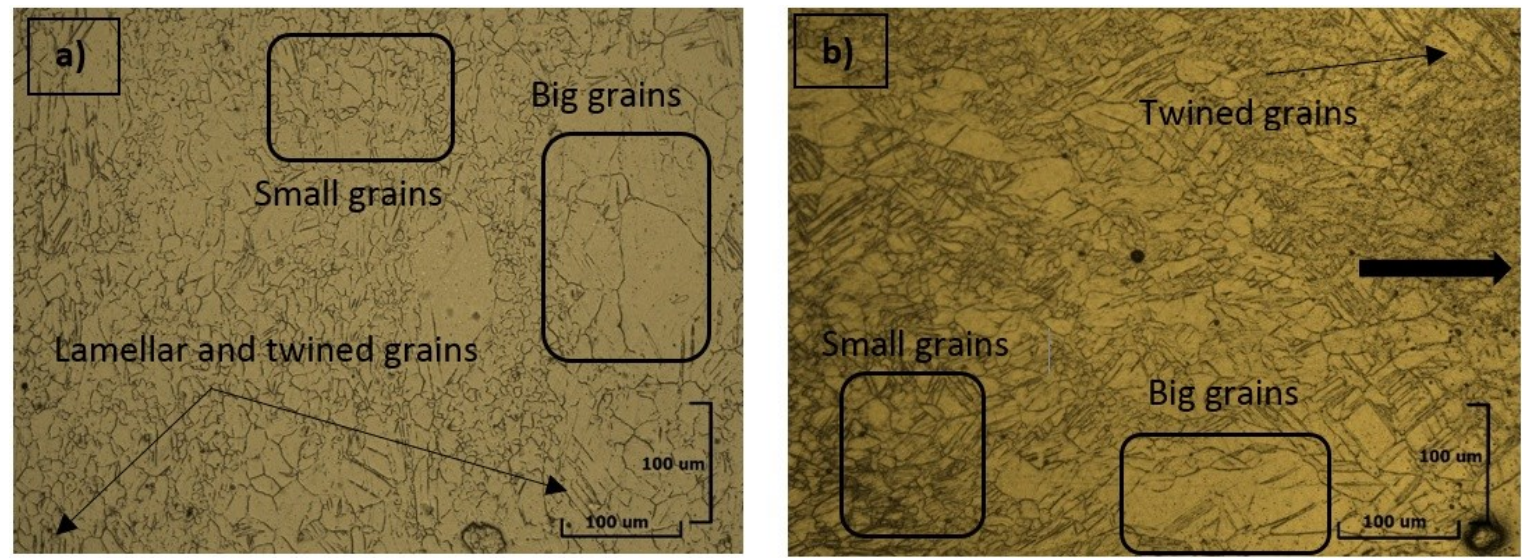

Figure 3: Bulk magnesium alloy microstructures (a) as-received, b) three ECASD passes. 
A close up of the zones that were in contact with the die (ECADS process) is shown in Figure 4. The contact zone was lubricated with graphite. As shown in Figure 4(a), some cracks are visible at low magnifications after three ECASD passes, but the cracks started to develop in the magnesium alloy just after the first pass. Both phenomena (cracks and grain shape) are due to the high Hertzian contact stresses developed during the ECASD process. As the aluminum alloy is a ductile material, grains at the surface were plastically deformed (see Figure 4(b)), and the cracks started to develop in the aluminum alloy just after the three passes.

The magnesium alloy samples show small grains near the surface, which can be due to a combination of stresses and temperature. Magnesium recrystallization temperature is about $200^{\circ} \mathrm{C}$ and can be reached during the ECASD process [20], so this refined microstructure could be associated to a dynamic recrystallization process.
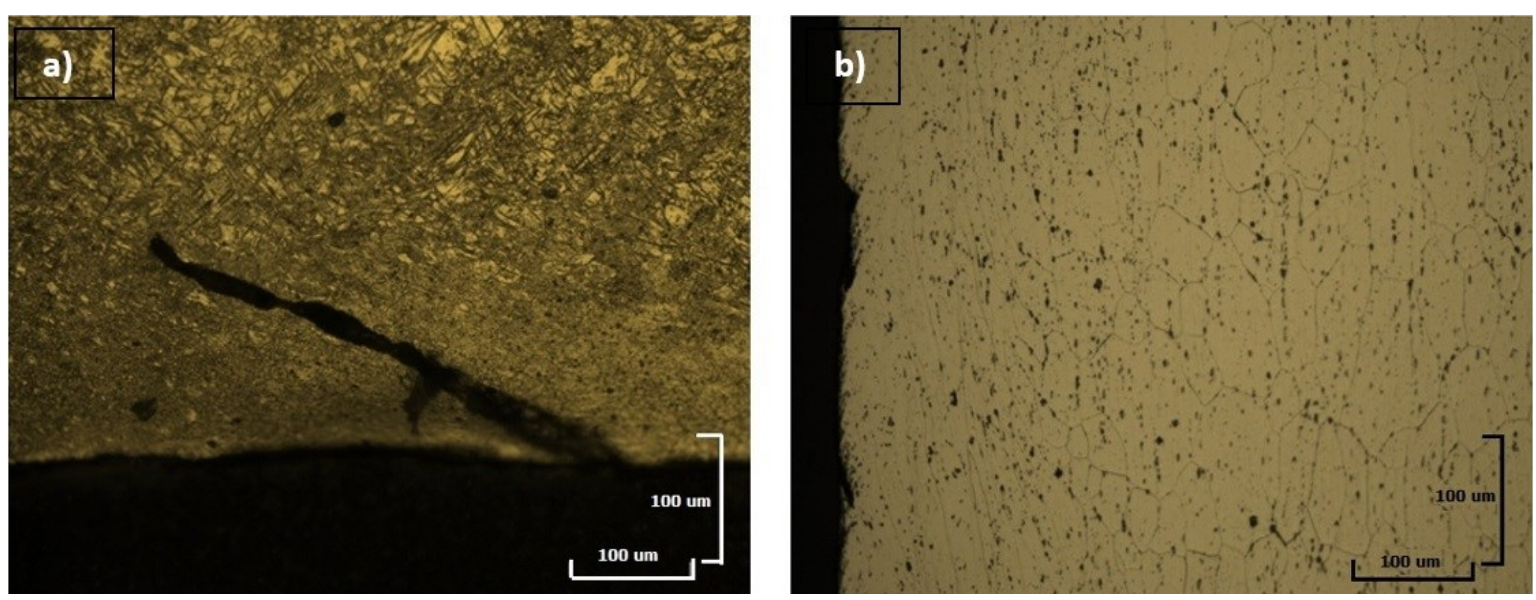

Figure 4: Close up of the AZ31B-O magnesium and aluminum alloys, which were at the contact zone with the die (passes refers to ECASD process) (a) Mg after 3 passes and (b) Al after 3 passes.

\subsection{Mechanical properties}

Figure 5 shows the micro-hardness evolution for magnesium and aluminum alloys sheets as function of the number of passes through the die. The indentations were performed at the core of the samples. The aluminum alloy has slower and lower hardening rate compared with the magnesium alloy, which shows faster hardening during first passes through the die.

The behavior at the surface is different compared with the core. The micro-hardness behavior near the contact surface are shown in Figure 6. In the case of aluminum alloy, the increase in the hardness is product of a severe plastic deformation as was shown in the microstructure in Figure 4(b). This alloy suffers a slow hardness increase during its first passes through the die. The magnesium alloy shows a different behavior compared with the aluminum alloy because at the first pass through the die the magnesium gets almost the maximum hardness achieved, which shows its low capacity for plastic deformation. This behavior can be attributed to the activated twinning and the re-crystalline structures near the surface for the magnesium alloy and work-hardening for aluminum alloy.

On the other hand, aluminum has a face cubic center structure and the mechanisms of plastic deformation allows for shearing of slip-dense-systems, which in turn allows for high deformation levels and also a progressive movement and stacking of the dislocations moving through the slip systems [21, 22], producing a steady increase of hardness. This is why the aluminum alloy shows a highly deformed microstructure at the surface. 


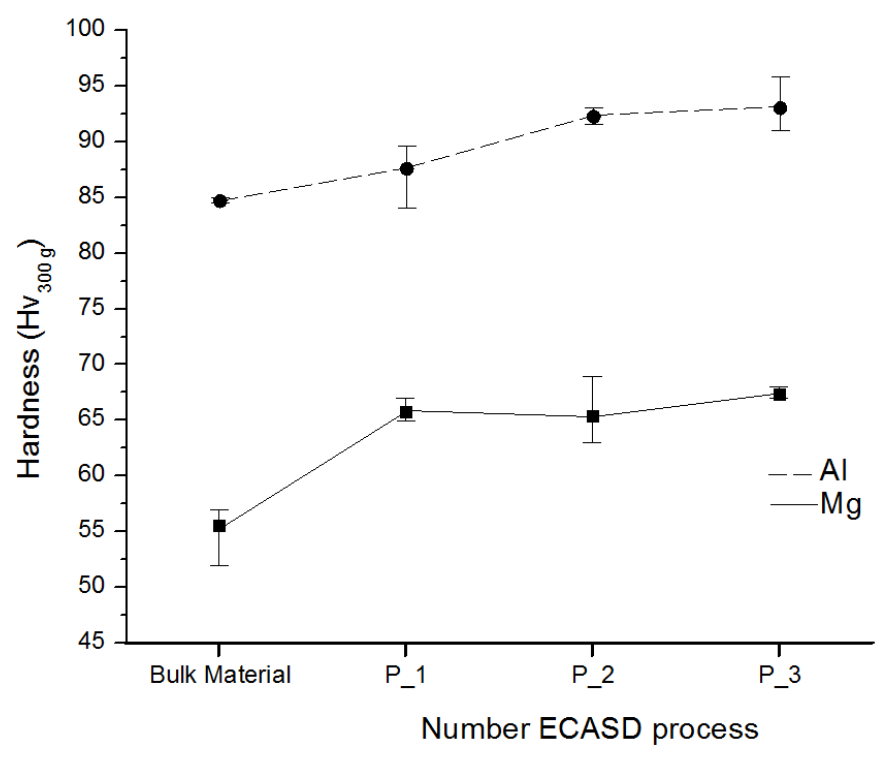

Figure 5: Micro-hardness evolution for the magnesium and aluminum alloys as function of number of passes through the die in an ECASD process.

By contrast, the magnesium has a low formability at room temperature that arises from the limited number of slip systems in the hexagonal close packed (HCP) Mg alloys. The dominant slip system of magnesium AZ31B alloy at room temperature is on the basal (0001) plane, thus, twinning is the main mechanism to produce the plastic deformation. This mechanism only allows low deformation levels and also limits the movement of the dislocations. Once the dislocations are stacked and stopped the material reaches a maximum allowable plastic deformation (maximum hardness) and turns to expend the mechanical stored energy into severe cracking as shown in Figure 4(a), as in agreement with [23].

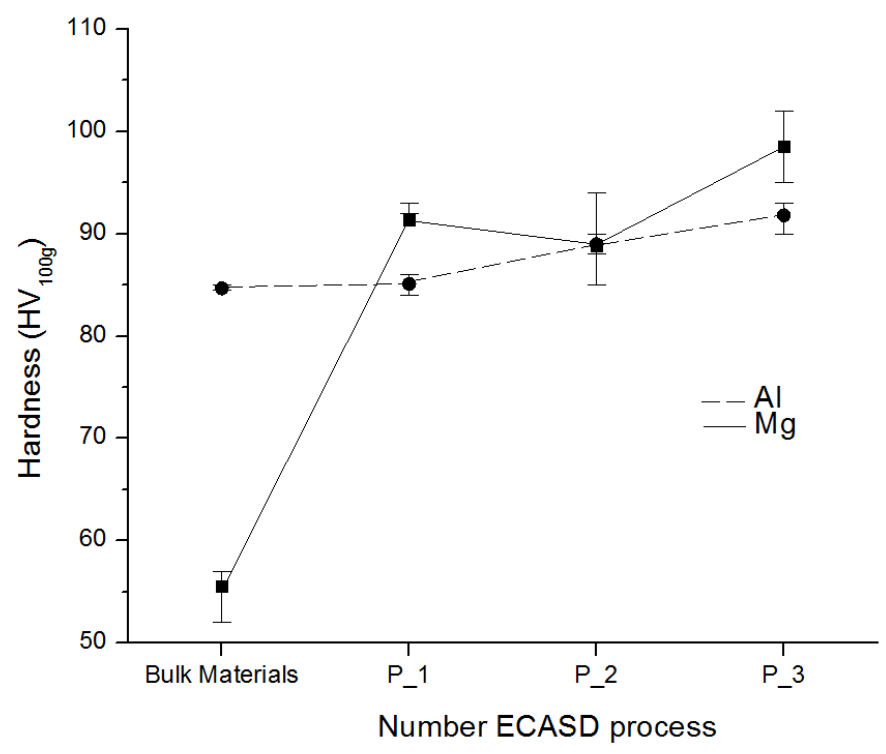

Figure 6: Micro-hardness close to the surface for both materials.

Figures 7 to 9 show the results for tensile test of magnesium and aluminum alloys processed by ECASD. The ultimate tensile strength (Figure 7), yield strength (Figure 8) and elongation (Figure 9) were analyzed. Figure 7 shows that ultimate tensile strength for aluminum alloy increase sharply after the first pass due to a lot of dislocations and refined grains introduced by ECASD process, mainly close to the surface, while magnesium alloy decreases its ultimate tensile strength with the ECASD passes. Clearly, these quite different behaviors are associated with the very different ductility of the materials. It is important to mention 
that the surface of the samples is polished after each pass in order to eliminate possible cracks. However, as this procedure was made with a fine grain emery paper, there is no guarantee that all the cracks were eliminated. Moreover, some small variations in the sample thickness can be introduced, which can put some variation in the macroscopic mechanical properties, particularly in the maximum strength that can be seriously affected by the presence of cracks in the case of the low ductile magnesium alloy.

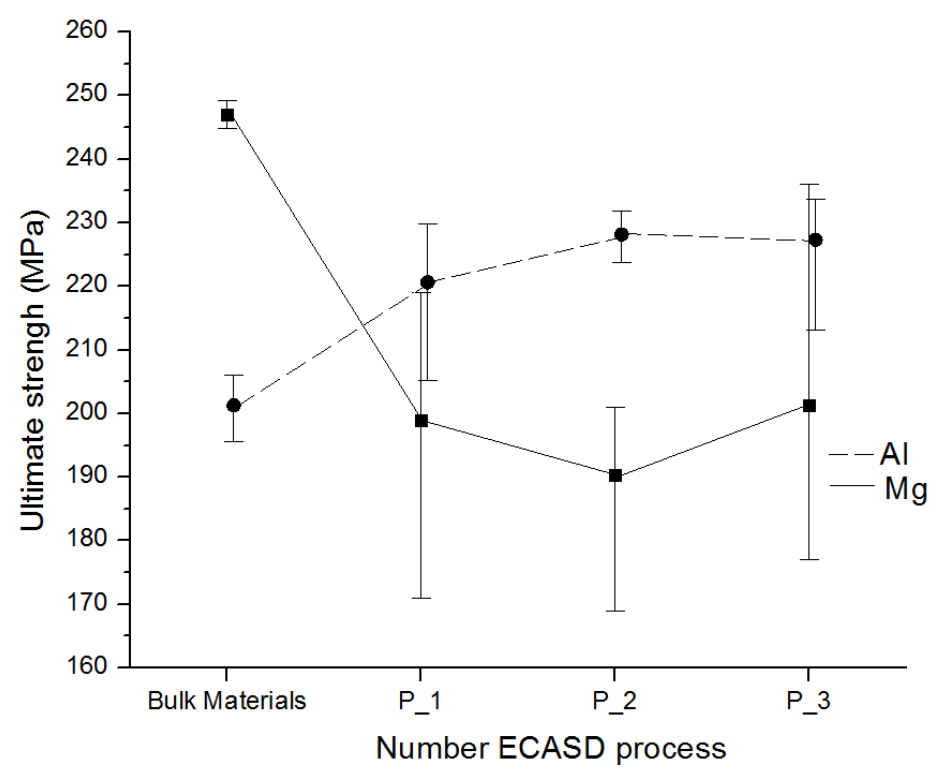

Figure 7: Ultimate strength for both material (aluminum and magnesium).

Figure 8 shows the variation of the yield strength for both materials. In either case, the property increases after the first pass of ECASD, however, the dispersion in the property in the magnesium alloy is due to the superficial cracks that appear in the first pass. A decrease in the ductility is shown in Figure 9 for both alloys, which is larger in the magnesium alloy, explained by the same arguments exposed above. A good combination of both strength and ductility was not found after three ECASD passes, and it was due to not achieve the good texturing microstructure. As shown in Y.J. Chen, et al [19], they found a good relationship between strength and ductility after six passes by severe plastic deformation process.

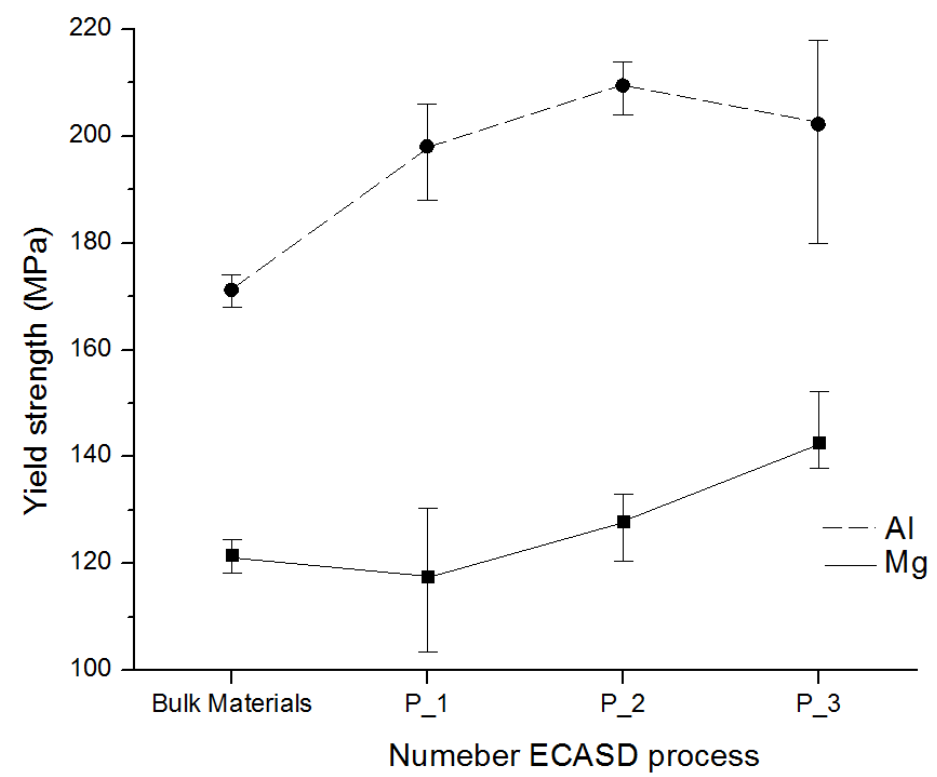

Figure 8: Yield stress for both material (aluminum and magnesium). 


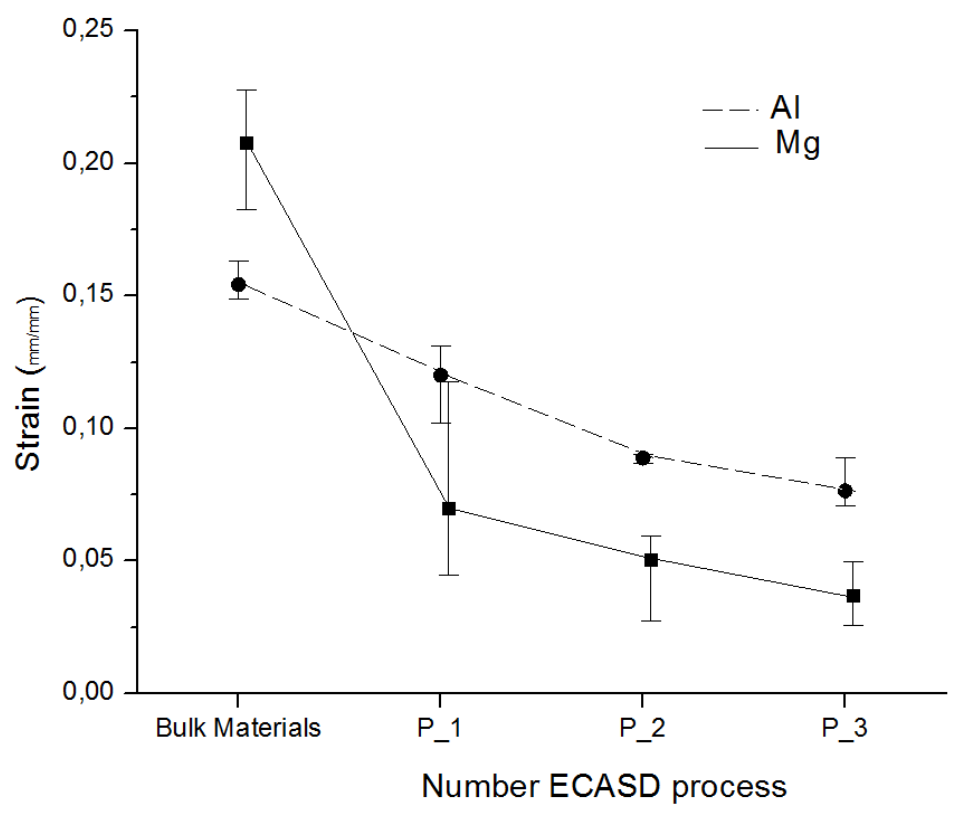

Figure 9: Strain for both material (aluminum and magnesium).

\section{CONCLUSIONS}

A combination of mechanical and microstructural techniques has been used to evaluate the changes due to severe plastic deformation process (Equal-Channel Angular Sheet Drawing), for light metallic materials such as aluminum and magnesium alloys. Results show that the ECASD process produces minimum microstructural changes into the core of the flat specimens for the alloys under study and microstructural changes are more evident close to the surface. The microstructure of both alloys is refined by the interaction and increasing of shear bands. The deformation includes two stages, first the grain refinement stage and second the twinning activation. This process also changes the mechanical properties; increasing both ultimate strength and yield strength with presence of cracks generated on the surface that seem not to play an important role for the mechanical behavior of aluminum alloys. On the other case, the magnesium alloy, its low ductility and non-homogeneous starting microstructure seems to be the cause of a slight increase in the yield strength as a function of ECASD passes and for its ultimate strength decrease.

\section{ACKNOWLEDGMENT}

Authors want to acknowledge the support of Universidad Pontificia Bolivariana, materials characterization lab of Universidad Nacional de Colombia-Sede Medellin. Colciencias have financially supported this work under grant 1210-569-34713

\section{BIBLIOGRAPHY}

[1] DUMITRU, F.-D., HIGUERA-COBOS, O.F., CABRERA, J. "ZK60 alloy processed by ECAP: Microstructural, physical and mechanical characterization", Materials Science and Engineering: A,v. 594, n. pp.3239,2014 .

[2] LINDEMANN, A., SCHMIDT, J., TODTE, M., et al. "Thermal analytical investigations of the magnesium alloys AM 60 and AZ 91 including the melting range", Thermochimica acta,v. 382, n. 1, pp.269275,2002 .

[3] SMERD, R., WINKLER, S., SALISBURY, C., et al. "High strain rate tensile testing of automotive aluminum alloy sheet”, International Journal of Impact Engineering, v. 32, n. 1, pp.541-560,2005.

[4] TAN, M., LIU, Z.M., QUAN, G.F. "Effects of Hot Extrusion and Heat Treatment on Mechanical Properties and Microstructures of AZ91 Magnesium Alloy”, Advanced Materials Research,v. 562, n. pp.242245,2012 .

[5] CHENG, Y.Q., CHEN, Z.H., XIA, W.J. "Drawability of AZ31 magnesium alloy sheet produced by equal channel angular rolling at room temperature", Materials Characterization v., n. pp.617-622, 2007.

[6] KOIKE, J., KOBAYASHI, T., MUKAI, T., et al. "The activity of non-basal slip systems and dynamic 
recovery at room temperature in fine-grained AZ31B magnesium alloys”, Acta Materialia,v. 51, n. 7, pp.2055-5065,2003.

[7] LANGDON, T.G. "The principles of grain refinement in equal-channel angular pressing", Materials Science and Engineering $A$,v. 462, n. 1-2, pp.3-11,2007.

[8] CHAKKINGAL, U., SURIADI, A.B., THOMSON, P.F. "The development of microstructure and the influence of processing route during equal channel angular drawing of pure aluminum", Materials Science and Engineering ,v. 266, n. 1-2, pp.241-249,1999.

[9] VALIEV, R.Z., LANGDON, T.G. "Principles of equal-channel angular pressing as a processing tool for grain refinement", Progress in Materials Science, v. 51, n. 7, pp.881-981,2006.

[10] SARAY, O., PURCEK, G., KARAMAN, I. "Principles of Equal-Channel Angular Sheet Extrusion (ECASE): Application to IF-Steel Sheets", Reviews on advanced materials science, v. 25, n. 1606-5131, pp.42-45,2010.

[11] YAMASHITA, A., HORITA, Z., LANGDON, T.G. "Improving the mechanical properties of magnesium and a magnesium alloy through severe plastic deformation", Materials Science and Engineering: A,v. 300, n. 1, pp.142-147,2001.

[12] UTSUNOMIYA, H., IZUMI, K.-i., SAKAI, T., et al. "Grain refinement of magnesium alloy sheets by ARB using high-speed rolling mill", Journal of Physics: Conference Series: IOP Publishing, 2009.

[13] ZISMAN, A.A., RYBIN, V.V., VAN BOXEL, S., et al. "Equal channel angular drawing of aluminium sheet", Materials Science and Engineering,v. 427, n. 1-2, pp.123-129,2006.

[14] SURIADI, A., THOMSON, P. Control of deformation history for homogenizing and optimizing mechanical properties of metals, Proceedings of Australiasia-Pacific Forum on Intelligent Processing \& Manufacturing of Materials, IPMM1997. pp. 920-926.

[15] ADEDOKUN, S. "A Review on Equal Channel Angular Extrusion as a Deformation and Grain Refinement Process", Journal of Emerging Trends in Engineering and Applied Sciences, v., n. pp.360-363,2011.

[16] LABORATORY, I.N.E.E. Equal Channel Angular Extrusion, Idaho, U.S. Department of Energy, 1999.

[17] CABIBBO, M. "A TEM Kikuchi pattern study of ECAP AA1200 via routes A, C, BC", Materials characterization, v., n. pp. 613-625,2010.

[18] JÄGER, A., LUKÁČ, P., GÄRTNEROVÁ, V., et al. "Influence of annealing on the microstructure of commercial Mg alloy AZ31 after mechanical forming", Materials Science and Engineering: A, v. 432, n. 1, pp.20-25,2006.

[19] CHEN, Y., CHAI, Y., ROVEN, H., et al. "Microstructure and mechanical properties of Al-xMg alloys processed by room temperature ECAP", Materials Science and Engineering: A, v. 545, n. pp.139-147,2012.

[20] AL-SAMMAN, T., GOTTSTEIN, G. "Dynamic recrystallization during high temperature deformation of magnesium", Materials Science and Engineering: A, v. 490, n. 1, pp.411-420, 2008.

[21] STOUT, M.G., MARTIN, P.L. "Multiaxial yield behavior of 1100 aluminum following various magnitudes of prestrain", International Journal of Plasticity,v.1, n.2, pp.163-174,1985.

[22] BARBOSA, J., GARCIA, I., FUENTES, J. "Estimación vía experimental de la formabilidad de láminas de aluminio de pureza comercial", Revista Latinoamericana de Metalurgía y Materiales, v29., n.2, pp.128134,2009 .

[23] TAN, M., ZHAOMING, L., QUAN, G. "Effects of Hot Extrusion and Heat Treatment on Mechanical Properties and Microstructures of AZ91 Magnesium Alloy", Energy Preocedia,v.16., pp.457-460,2012. 